\title{
EFFECTS OF ULTRAVIOLET-B RADIATION IN PLANT PHYSIOLOGY
}

\author{
RANA NASSOUR*, ABDULKARIM AYASH
}

Al-Andalus University for Medical Sciences, Tartous, Syria

Nassour, R. and Ayash, A. (2021). Effects of ultraviolet-B radiation in plant physiology. Agriculture (Pol'nohospodárstvo), $67(1), 1-15$.

\begin{abstract}
Over the past few decades, anthropogenic activities contributed to the depletion of the ozone layer, which increased the levels of solar ultraviolet-B (UV-B) radiation reaching the Earth`s surface. Generally, UV-B is harmful to all living organisms. It damages the cell`s Deoxyribonucleic acid (DNA), proteins, and lipids, and as a consequence, it affects the bio-membranes negatively. In this review, we summarize the major effects of UV-B in the plant's main molecules and physiological reactions, in addition to the possible defence mechanisms against UV-B including accumulating UV-B absorbing pigments to alleviate the harmful impact of UV-B.
\end{abstract}

Key words: ultraviolet-B radiation, reactive oxygen species, respiration, photosynthesis, phenolic compounds

Solar radiation is a part of the electromagnetic field and is considered an essential condition for life on Earth. The electromagnetic spectrum includes different types of waves; gamma radiation $(<0.1 \mathrm{~nm})$, X-rays $(0.1-100 \mathrm{~nm})$, ultraviolet radiation $(100-390 \mathrm{~nm})$, visible waves $(390-780 \mathrm{~nm})$, infrared radiation $(780 \mathrm{~nm}-1 \mathrm{~mm})$, microwaves $(1 \mathrm{~mm}-1 \mathrm{~cm})$ and radio waves $(1 \mathrm{~cm}-100 \mathrm{~km})$ (Sliney \& Chaney 2006; Mandi 2016; Zwinkels 2016).

Although visible light forms only a very small part of the entire sun's electromagnetic spectrum, it provides the energy needed for plants to perform photosynthesis, the most important process for the production of reduced carbon (e.g. carbohydrates, amino acids, fatty acids, etc.) and oxygen. That makes photosynthesis the main source of building blocks and energy-supplying molecules in living organisms.
Ultraviolet (UV) radiation comprises three types of waves varying by their wavelengths and energy: UV-C (100-280 nm), UV-B (280-320 nm), and UV-A (320-390 nm). UV-C has the highest energy level and it is the most hazardous part of the ultraviolet radiation. Luckily, it is completely absorbed by the atmospheric oxygen $\left(\mathrm{O}_{2}\right)$ and stratospheric ozone $\left(\mathrm{O}_{3}\right)$, while most of the UV-B radiation is absorbed efficiently by $\mathrm{O}_{3}$, and UV-A is fully transmitted to the Earth's surface to a large extend (Madronich et al. 1998; Mandi 2016). In this context, the ozone acts as a natural barrier to the Earth from sunlight and its effects. It blocks and isolates harmful UV radiation before it reaches the surface of our planet, damaging the cells of humans and other organisms.

The stratospheric ozone is continuously produced and broken down according to a natural pro-

Rana Nassour (*Corresponding author), Department of Basic Science, Faculty of Pharmacy, Al-Andalus University for Medical Sciences, Tartous, Syria. E-mail: ranahn1985@gmail.com

Abdulkarim Ayash, Department of Basic Science, Faculty of Pharmacy, Al-Andalus University for Medical Sciences, Tartous, Syria. E-mail: abdulkarimayash@gmail.com 
cess with dynamic equilibrium, via oxygen photolysis by short ultraviolet radiation (UV-C shorter than $250 \mathrm{~nm}$ ). The released atomic oxygen $(\mathrm{O})$ then bonds with molecular oxygen $\left(\mathrm{O}_{2}\right)$, resulting in ozone $\left(\mathrm{O}_{3}\right)$. The $\mathrm{O}_{3}$ is then broken down by long ultraviolet radiation (UV-B) to produce $\mathrm{O}_{2}$ and $\mathrm{O}$, according to the following equations (Häder 1991; Mandi 2016):

$$
\begin{gathered}
\mathrm{O}_{2} \stackrel{\text { short UV radiation }(>250 \mathrm{~mm})}{\longrightarrow} 2 \mathrm{O} \\
2 \mathrm{O}+2 \mathrm{O}_{2} \longrightarrow 2 \mathrm{O}_{3} \\
2 \mathrm{O}_{3} \stackrel{\text { long UV radiation (UV-B) }}{\longrightarrow} 2 \mathrm{O}+2 \mathrm{O}_{2}
\end{gathered}
$$

Unfortunately, the ozone layer has been undergoing a gradual decline in its quantity for nearly four decades due to gaseous pollutants, such as chlorinated fluorocarbons (CFCs), chloroform, hydrochlorofluorocarbons (HCFCs), carbon tetrachloride, methyl bromide, and reactive nitrogen species (nitric oxide, nitrous oxide, etc.) (Rastogi et al. 2014; Sreelakshmi \& Raza 2014; Mandi 2016). These stable compounds can remain in the upper atmosphere for millions of years (20-100 million years), where chlorine and bromine atoms are released from them via UV. Each atom, which acts as a free radical, is capable of initiating a series of reactions that can destroy more than 100,000 ozone molecules. This significant destruction of $\mathrm{O}_{3}$ reduces the UV absorption efficiency, so more of this radiation reaches the surface of the Earth ( $1 \%$ reduction of $\mathrm{O}_{3}$ causes $1.3-1.8 \%$ increase of UV-B on the Earth's surface) (Caldwell \& Flint 1994; Sivasakthivel \& Reddy 2011; Lidon et al. 2012).

It's worth noting that due to the ban of hydrochlorofluorocarbons according to the 1987 Montreal Protocol, the ozone layer is about to recover, although there is still a long way to go (Chipperfield et al. 2017). Still, latitudes between $60^{\circ} \mathrm{S}$ and $60^{\circ} \mathrm{N}$ did not show recovery for unclear reasons (Ball et al. 2018).

\section{UV-B INDUCES REACTIVE OXYGEN SPECIES PRODUCTION}

Reactive oxygen species (ROS) are toxic by-products generated during metabolism, even under natural conditions. They are produced in plants in various subcellular sites, including mitochondrial respiration, photosynthesis, and photo-respiratory reactions (Mhamdi \& Breusegem 2018).

Plants possess an antioxidant system to protect their cells from ROS. The major antioxidants are enzymes, including superoxide dismutase (SOD), catalase (CAT), various peroxidases like ascorbate peroxidase (APX), and glutathione peroxidase (GPX). Besides, there are some low molecular weight antioxidants (LMWAs) in plant cells, such as ascorbate (vitamin $\mathrm{C}$ ), tocopherols (vitamin E), $\beta$-carotene, and phenolic compounds such as the flavonoids (Ren et al. 2006; Hatier \& Gould 2009; Reboredo \& Lidon 2012; Zlatev et al. 2012; Fu \& Shen 2017; Zhang et al. 2017; Bhattacharjee 2019).

ROS formation increases in the plant cell under stress conditions, such as ultraviolet radiation due to their high-energy photons that damage the cell structure (oxidize proteins, lipids, and other biomolecules), disrupt the functionality and integrity of enzymes and cell membranes, and cause an imbalance in the redox reactions. So, a considerable part of the electrons leaks from electron transport systems to oxygen $\left(\mathrm{O}_{2}\right)$, reducing it to superoxide free radical $\left(\mathrm{O}_{2}^{-}\right)$(Hideg et al. 2013; Bhattacharjee 2019; Dmitrieva et al. 2020).

In general, it is agreed that chloroplasts are the major sources of ROS in the plant cell, particularly under illumination, while the mitochondria are the main source of ROS in the darkness and nongreen parts of the plant. The excitation of oxygen $\left(\mathrm{O}_{2}\right)$ produces singlet oxygen $\left({ }^{1} \mathrm{O}_{2}\right)$, while reduction produces superoxide radicals $\left(\mathrm{O}_{2}^{-*}\right)$, hydrogen peroxide $\left(\mathrm{H}_{2} \mathrm{O}_{2}\right)$, and hydroxyl radicals $\left(\mathrm{OH}^{\circ}\right)$, (Figure 1) (Mhamdi \& Breusegem 2018). Chloroplasts produce ${ }^{1} \mathrm{O}_{2}, \mathrm{O}_{2}{ }^{--}$and $\mathrm{H}_{2} \mathrm{O}_{2}$ during photosynthetic electron transport, whereas mitochondria produce $\mathrm{O}_{2}$ - mainly at complex I and III of electron transport chain (Bhattacharjee 2019; Huang et al. 2019). The latter can be explained by the direct reduction of oxygen to $\mathrm{O}_{2}^{-}$in complex I (the flavoprotein region of $\mathrm{NADH}$ (reduced nicotinamide adenine dinucleotide) dehydrogenase segment). Regarding complex III (the ubiquinone-cytochrome region), it is believed that fully reduced ubiquinone donates an electron to cytochrome $\mathrm{C} 1$ and leaves an unstable highly reducing ubisemiquinone radical that is favourable for the electron leakage to $\mathrm{O}_{2}$ and, hence, to $\mathrm{O}_{2}^{-}{ }^{-}$formation 
(Bhattacharjee 2019). The increased production of ROS in living organisms under stress conditions is very toxic because it can react with vital biomolecules, altering and reducing their biochemical activities, causing oxidative damage and eventually resulting in cell death (Jithesh et al. 2006; Piri et al. 2011; Pessoa 2012; Zlatev et al. 2012; Kataria et al. 2014; Yokawa et al. 2016)

\section{UV-B EFFECTS IN PLANTS}

Although UV-B is just a small fraction of the electromagnetic field, it adversely affects the lives of all living organisms, including plants. Plants ex- posed to UV exhibit a decline in photosynthesis, protein synthesis, and other biochemical processes. These impairments lead to the reductions in plant height, dry weight, leaf area, relative growth rate, and total biomass (Caldwell et al. 2007; Kumari et al. 2009; Piri et al. 2011; Reddy et al. 2013; Bacelar et al. 2015; Reyes-Díaz et al. 2016; Fina et al. 2017; Fu \& Shen 2017; Rai \& Agrawal 2017; Neugart \& Schreiner 2018; Parani \& Vidhya 2018; Alves \& Deschamps 2019; Alemu \& Gebre 2020), an increase in the leaf thickness and downward leaf curling (Golaszewska et al. 2003; Bacelar et al. 2015; Rai \& Agrawal 2017), and a decline in transpiration rate,

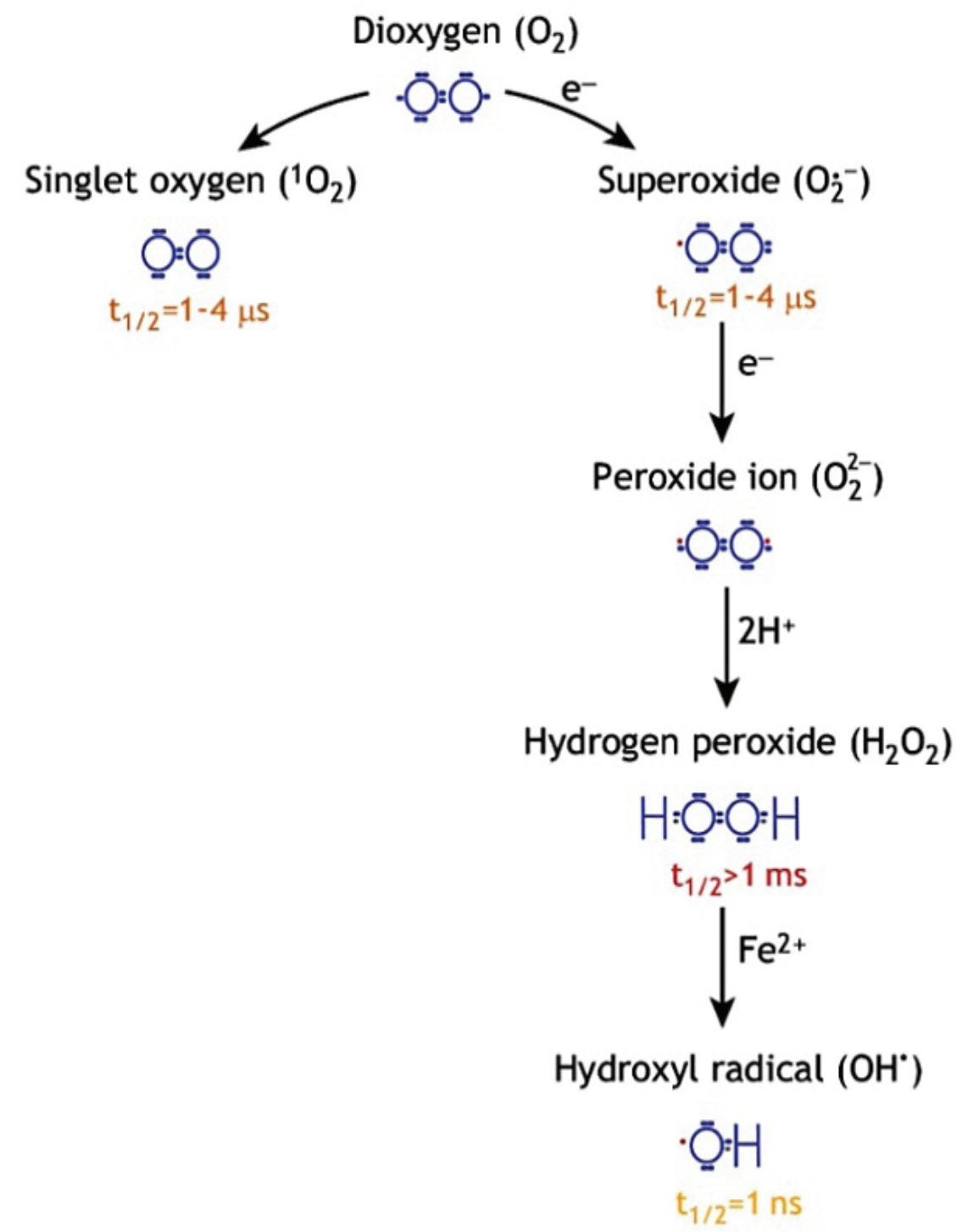

Figure 1. Oxygen-derived reactive oxygen species (Mhamdi \& Breusegem 2018)

Note: $\mathrm{e}^{-}-$electron; $2 \mathrm{H}^{+}-2$ protons; $\mathrm{Fe}^{2+}-$ iron divalent ion; $\mathrm{t}_{1 / 2}-$ the half-life time; $\mu \mathrm{s}-$ microsecond; $\mathrm{ns}$ - nanosecond; $\mathrm{ms}-$ millisecond 
beside a delay in flowering and fruiting (Bassman et al. 2003; Reddy et al. 2013; Rai \& Agrawal 2017). In addition, many studies referred to the negative impact of UV-B on stomatal conductance, which reduces the amount of $\mathrm{CO}_{2}$ available for photosynthesis (Cechin et al. 2007; Lidon et al. 2012; Bacelar et al. 2015; Cechin et al. 2018; Reyes et al. 2018; Reyes et al. 2019).

\section{$U V-B$ effects in cellular compounds}

UV-B forms a small part of the electromagnetic field, yet it is very energetic affecting and modifying a wide range of important biochemicals and breaking them into smaller molecules. That makes it destructive for the organism's life in general.

Proteins: UV-B has negative effects on structural and functional proteins. It destroys the peptide bonds in the protein and breaks them into polypeptides. Proteins highly absorbance to UV-B (around $280 \mathrm{~nm}$ ) is due to the absorbance of their aromatic amino acids (such as tyrosine, phenylalanine, tryptophan, histidine, and cysteine), so they are considered as one of the main targets for UV-B (Nawkar et al. 2013; Parihar et al. 2017).

Proteins may undergo photomodification directly through photooxidation reactions or indirectly by the photosensitized production of reactive oxygen species (ROS) and free radicals. Ultraviolet radiation modifies the structure of amino acids, which leads to protein denaturation and enzyme deactivation. This can be due to UV-B destruction of aromatic amino acids (free and within proteins), or to its effect on the disulphide bonds (S-S) in amino acids, which contain a sulfhydryl group in their reaction centre (Hollosy 2002; Vass et al. 2005; Xue et al. 2005; Castenholz and Garcia-Pichel 2012; Nawkar et al. 2013; Wang et al. 2017).

Lipids: When exposed to UV-B, lipids undergo lipid peroxidation whether they are glycolipids, phospholipids, or unsaturated fatty acids. UV-B exposed phospholipids are sensitive to ROS in two sites: the unsaturated double bond between the carbon atoms and the ester bond between glycerol and fatty acids (Kramer et al. 1991; Moorthy \& Kathiresan 1998; Hollosy 2002; Bhandari \& Sharma 2006; Noaman 2007; Pérez et al. 2012; Ganapathy et al. 2017; Wang et al. 2017). Polyunsaturated fatty acids (PUFAs) in the membrane's phospholipids are also sensitive to ROS; since hydroxyl radical and singlet oxygen can react with methylene groups of PUFA and form lipid peroxy radicals and hydroperoxide. In their turn, the peroxy radicals can abstract hydrogen from other unsaturated fatty acids, leading to a chain reaction of peroxidation (Nasibi \& M-Kalantari 2005; Vass et al. 2005; Rastogi et al. 2014; Sharma et al. 2014; Kumar et al. 2018).

Based on the above, the negative impact of UV-B causes destruction of biomembranes (cellular membranes, mitochondrial membranes (cristae), thylakoids, tonoplast, etc.), because each one of these membranes consists of a bilayer of phospholipids with proteins interspersed throughout. Therefore, any damage to the components of these membranes will lead to rupture them and disrupt the biochemical reactions in them (Bidlack \& Jansky 2018).

Carbohydrates: they are the main product of photosynthesis. Carbon is fixed in C3-plants within Calvin cycle in the form of phosphorylated triose and then convert to glucose, which binds to each other to be stored as polysaccharides. UV-B causes a steep drop in total carbohydrate content either directly by inhibition of enzymes involved in the Calvin cycle, or indirectly by inhibition of the photochemical reactions required to produce $\mathrm{NADPH}+\mathrm{H}^{+}$and ATP needed for the Calvin cycle (Prasad et al. 1998; Bhandari \& Sharma 2006; Ganapathy et al. 2017; Kurinjimalar et al. 2019; Reyes et al. 2019).

Deoxyribonucleic acid (DNA): UV-B damages nuclear, mitochondrial, and chloroplast DNA by indirect oxidative stress or direct absorption of purines and pyrimidines to these wavelengths (between 220-300 nm), although pyrimidines are more affected. DNA lesions induced by UV-B include dimers between two adjacent pyrimidine bases, cissyn cyclobutane pyrimidine dimers (CPDs), especially thymine dimers (TTs) and pyrimidine $(6-4)$ pyrimidone photoproducts [(6-4)PPs] (Draper \& Hays 2000; Sinha et al. 2001; Frohnmeyer \& Staiger 2003; Roleda et al. 2006; Babele et al. 2012; Pfeifer \& Besaratinia 2012; Nawkar et al. 2013; Rastogi et al. 2014; Gill et al. 2015; Li et al. 2015; Robson et al. 2019). These DNA lesions together can act as the principal cause of UV-B induced growth inhibition in plants. Additionally, these photoproducts block 
the activity of DNA and RNA polymerases along the DNA strand, which inhibit replication and transcription, respectively, and can lead to genetic code misreading and causing mutations and death (Sinha et al. 2001; Takahashi et al. 2015; Jansen 2017).

UV radiation causes a decline in the cell division rates as well as in cell number. This can be due to the genetic material destruction and disrupting transcription processes (as mentioned above) beside inhibition of protein synthesis in $\mathrm{G} 1$ - S phases of the cell cycle (Buma et al. 1996; Nogués et al. 1998; Hopkins et al. 2002; Juan et al. 2005; Gill et al. 2015). Jiang et al. (2011) implied that UV-B-induced $\mathrm{G} 1$ to $\mathrm{S}$ arrest may be a protective mechanism that prevents cells with damaged DNA from dividing and may explain the plant growth inhibition under increased solar UV-B. Besides, UV-B-treated cells age more quickly than those of the controls (Hopkins et al. 2002).

\section{Effect of $U V-B$ in respiration}

A very few studies investigated the impact of UV-B on respiration. Under UV-B stress, respiration increase significantly in the plant cell. This increment can be explained by the rise of energy demands, which is used in protection and repair mechanisms, including the increase of the leaf thickness and phenolic compounds biosynthesis (GwynnJones 2001; Bassman \& Robberecht 2006; Suchar \& Robberecht 2016).

\section{Effect of UV-B in photosynthesis}

Photosynthesis is the most important process in the plant, because it is the main source of organic matter on our planet, besides being responsible for producing and releasing oxygen to the Earth's atmosphere, which is essential for the respiration of aerial organisms. UV-B affects photosynthetic apparatus in many sites as the following:

\section{Effects of UV-B in pigmentation}

Photosynthetic pigments are bound to structural proteins in the thylakoid membranes in higher plants and algae to form Light-harvesting complexes (LHCs) within photosystem II (PSII) and photosystem I (PSI). Researches indicate that high intensity of UV-B leads to a functional disconnection between LHC and photosystems (particularly within PSII), which impairs the absorbed energy transfer to the reaction centres (Bornman 1989; Takeuchi et al. 2002; Kataria et al. 2014).

UV-B reduces the content of photosynthetic pigments in the chloroplast, especially chlorophyll $a$, which is considered the principal pigment in photosynthesis (Qi et al. 2003; Gupta et al. 2008; Juozaityte et al. 2008; Lidon \& Ramalho 2011; Singh \& Singh 2014; Sztatelman et al. 2015; Ayash et al. 2017; Fu \& Shen 2017; Sebastian et al. 2018). This loss in chlorophyll can be attributed to protochlorophyllide photoreduction to chlorophyllide by protochlorophyllide oxidoreductase during the early stages of chlorophyll biosynthesis, as well as chlorophyllase induction, which is responsible for chlorophyll breakdown (Agrawal 1996; Marwood \& Greenberg 1996; Pradhan et al. 2006; Sakalauskaite et al. 2013; Ganapathy et al. 2017; Rai \& Agrawal 2017).

Concerning carotenoids, they are photosynthetic accessory pigment. They invariably increase in response to UV-B (Kurinjimalar et al. 2019).

Effects of UV-B in the thylakoid membranes

The thylakoid membranes consist of a bilayer of phospholipids with proteins interspersed throughout. UV-B destroys the basic components of these membranes (proteins and phospholipids), leading to rupture them partially or completely, thus preventing the binding of electron acceptors, and disrupting photoelectron transport (Sinha et al. 2001; Lidon \& Ramalho 2011; Kataria et al. 2014; Allorent et al. 2016; Bidlack \& Jansky 2018).

Based on the mentioned above, many studies revealed that UV-B increases the permeability of thylakoids membranes, which causes protons leakage to stroma and lowers ATP synthesis rates (Salama et al. 2011; Zlatev et al. 2012; Rai \& Agrawal 2017). Also, swelled, disintegrated, and scattered thylakoids and the absence of grana can be noticed under UV-B stress (Yu et al. 2013).

\section{Effects of UV-B in light reactions}

PSII: PSII is a multifunctional pigment-protein complex embedded in the thylakoid membranes, especially in the grana regions of the chloroplasts. This complex contains more than 20 protein subunits and redox components that mediate light-induced electron transport (Vass et al. 2005). Many negative effects of UV-B have been reported in dif- 
ferent sites of PSII, including the following:

- Oxygen evolving complex (OEC): It is located in the lumenal side of the thylakoids, and includes four manganese atoms and one calcium atom forming a $\mathrm{Mn}_{4} \mathrm{Ca}$ cluster (Najafpour \& Govindjee 2011). According to Kok scheme, Mn shifts between five states during water oxidation ( $\mathrm{S} 0, \mathrm{~S} 1$, S2, S3, S4), releasing one proton and one electron in each state. The outcome of this process is the evolving of four electrons, four protons, and an oxygen molecule (Figure 2). Various studies indicated that UV-B might inhibit the OEC complex directly by absorbing this radiation via the Mn cluster, which breaks the bonds between the manganese atoms, or by damaging the intermediates of the water evolving process. There is a gradual increase of UV-B sensitivity from S0 to S3 due to increased susceptibility to absorption of these rays, which may result in the separation of the $\mathrm{Mn}-\mathrm{OH}$ bond and the formation of the hydroxyl radical and thus obstruct the release of oxygen (Sicora et al. 2006; Szilárd et al. 2007; Vass 1996; Vass 2012; Kataria et al. 2014; Allorent et al. 2016; Ayash et al. 2018; Mosadegh et al. 2019).

- D1 protein: It is one of the most important structural protein $(38.021 \mathrm{kDa})$ of PSII, binding essential electron transporters such as tyrosine (Tyr-Z) (Barber 2014). Under UV-B, D1 is degraded to a $20 \mathrm{kDa}$ fragment which is subsequently completely degraded by proteases enzymes in a light-dependent manner (Bergo et al. 2003). Besides the stability decrement of D1 and imbalance between its synthesis and breaking down

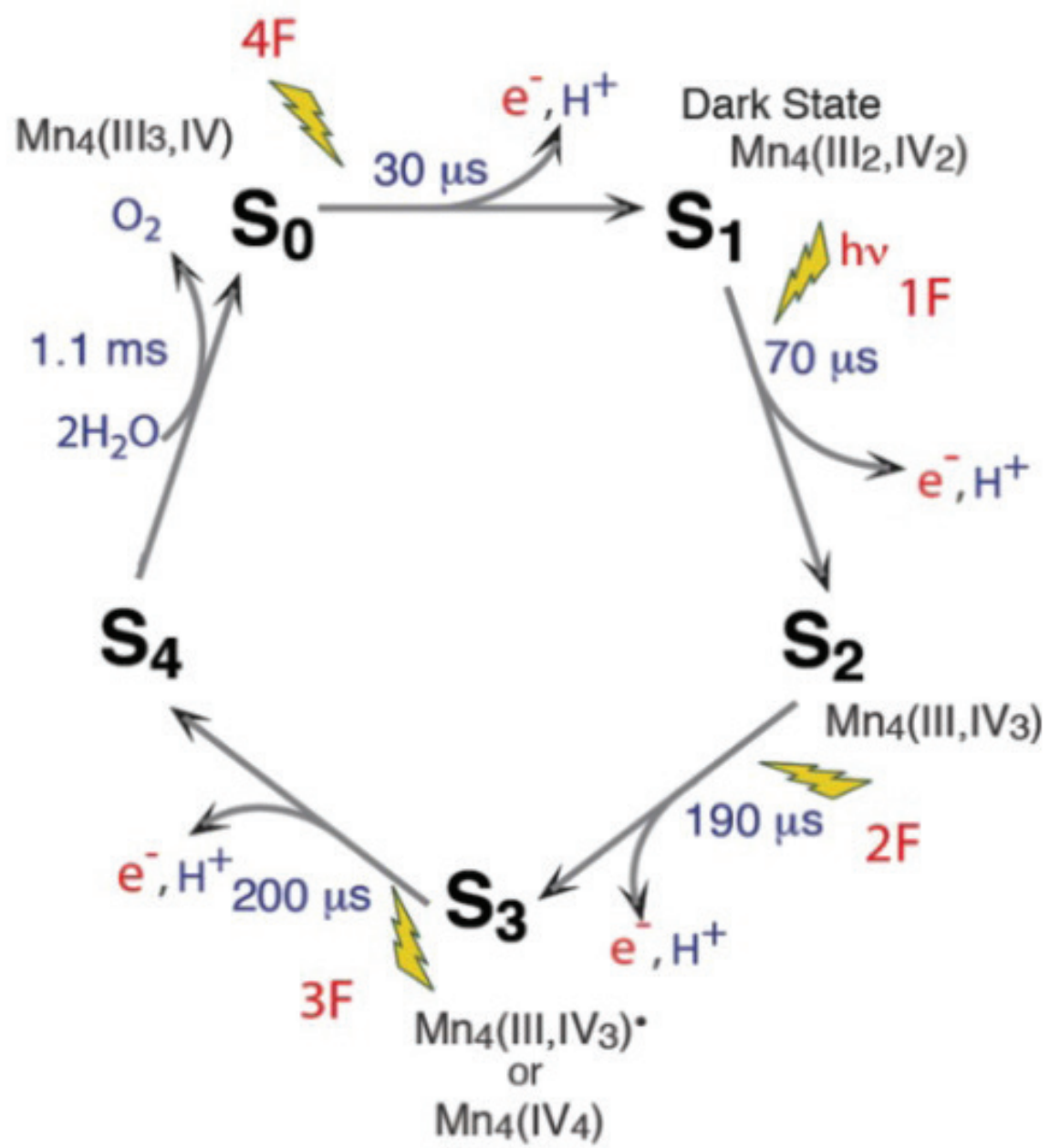

Figure 2. S-state Kok scheme (Yano \& Yachandra 2014)

Note: hv - light; $\mu \mathrm{s}$ - microsecond; $\mathrm{ms}$ - millisecond; $\mathrm{e}^{-}$- electron; $\mathrm{H}^{+}$- proton; $\mathrm{F}$ - flash 
rates, as the amount of ROS increases (in particular the active atomic oxygen) (Booij-James et al. 2000; Beardall \& Raven 2004; Holzinger \& Lütz 2006; Cai et al. 2016; Tilbrook et al. 2016; Parihar et al. 2017).

- Tyrosine: Released electrons from OEC are transferred to the reaction centre (RC) of PSII (P680) via a redox-active tyrosine residue (Tyr-Z) of the D1 protein. PSII contains another redox-active tyrosine, called Tyr-D (on the D2 subunit) which can donate electrons to P680, but is not involved in electron transfer from OEC (Sicora et al. 2003). Under UV-B, tyrosine may be inactivated and/or photo-oxidized to 3,4-dihydroxyphenylalanine (DOPA) and form di-tyrosine as a result (Vass 1996; Vass et al. 2005; Parihar et al. 2017).

- D2 protein: It is considered an essential structural protein $(39.418 \mathrm{kDa})$ of PSII, binding crucial electron transporters, such as plastoquinone (PQ) (Barber 2014). A significant decrease in D2 content is reported in the exposed to UV-B thylakoids (Booij-James et al. 2000; Tilbrook et al. 2016; Parihar et al. 2017).

- Plastoquinone: It is the mobile charge carrier responsible for the electron transport from PSII to cytochrome $b_{6} / f\left(\mathrm{Cyt} b_{6} / f\right)$. PQ is double reduced and takes up two protons from the stroma to become quinol (PQH2). Then, the lipophilic PQH2 is separated from protein D1 and moves within the lipid bilayer of the thylakoid membrane, transferring the electrons to Cyt $b_{6} / f$, releasing protons into the lumen, and returning to the oxidized form (PQ) (Eerden et al. 2017). Since main absorption of quinones in the UV region (oxidized PQ: $250 \mathrm{~nm}$, redox PQ; quinol (PQH2): $280 \mathrm{~nm}$ and semiquinone (PQH): $320 \mathrm{~nm}$ ), they can be destroyed, modified, or lost in the thylakoids exposed to UV, preventing protons from binding to them (Melis et al. 1992; Vass et al. 2005; Rensen et al. 2007).

Cytochrome $b_{6} / f$ : The Cyt $b_{6} / f$ complex (217 $\mathrm{kDa}$ ) consists of four large subunits (18 to $32 \mathrm{kDa}$ ), including cytochrome $\mathrm{f}$, cytochrome $\mathrm{b}_{6}$, the Rieske iron-sulfur protein (ISP), and subunit IV, together with four small hydrophobic subunits (PetG, PetL, PetM and PetN) (Kurisu et al. 2003). This complex mediates the electron transport chain between photosystems II and I; it oxidizes PQH2 produced by
PSII and reduces plastocyanin (PC - the electron donor for PSI) (Vass et al. 2005). The previous studies suggest that the Cyt $b_{\sigma} / f$ complex is the least affected thylakoid component by UV-B, which can be explained by the fact that $\mathrm{Cyt} b_{6} / f$ complex contains two quinine binding sites (one of them for quinol oxidation and the other for quinone reduction). Besides the UV-B minor sensitivity for genes encoded in the chloroplast, such as subunit IV of this complex (Kataria et al. 2014; Parihar et al. 2017).

PSI: PSI of higher plants contains approximately 15 protein subunits. PsaA and $\mathrm{PsaB}$ (each $\approx 80 \mathrm{kDa}$ ) form the central heterodimer of the reaction centre and most of the electron carriers and pigments of LHCI are bound to them (Niyogi et al. 2015). Uneven distribution of the effect of UV-B has been demonstrated by various studies to display minor or no effects on PSI compared to PSII (Hollosy 2002; Kataria et al. 2014; Parihar et al. 2017). This can be attributed to the significant down-regulation of many genes encoding PS I protein subunits in UVB-exposed cells (Kataria et al. 2014).

ATPase complex: The ATPase is a large ( $400 \mathrm{kDa})$ enzyme complex responsible for adenosine triphosphate (ATP) synthesis. It consists of two parts: a hydrophobic membrane-bound portion called coupling factor $\mathrm{O}(\mathrm{CFo})$ and another portion that sticks out into the stroma called coupling factor 1 (CF1). CFo forms a channel across the membrane for protons to pass through. CF1 is responsible for binding inorganic phosphate $(\mathrm{P})$ to adenosine diphosphate (ADP) to produce ATP. It is made up of several peptides; including three copies of each of $\alpha$ and $\beta$ peptides arranged alternately (Taiz \& Zeiger 2010). ATPase is significantly affected by UV-B, as the amount of coupling factor (CF1) decreases, as well as the activity of the whole complex (photophosphorylation). The later can be due to minimizing the difference of the proton concentrations between the two sides of the thylakoid membrane (stroma and lumen), caused by the changes in the thylakoid permeability (Zhang et al. 1994; Yu et al. 2013; Parihar et al. 2017).

Effect of UV-B in Calvin cycle enzymes:

The Calvin cycle is the primary cyclic pathway of carbon fixation and in higher plants is located in the stroma. The light reactions provide reducing 
power represented by the reduced form of nicotinamide adenine dinucleotide phosphate $\mathrm{NADPH}+\mathrm{H}^{+}$ and energy as ATP (Heineke \& Scheibe 2007).

The Calvin cycle can be subdivided into three phases: (i) the carboxylation of ribulose 1,5-bisphosphate (RuBP), leading to the formation of two molecules of 3-phosphoglycerate (3PGA), (ii) the reduction of 3PGA, and (iii) the regeneration RuBP. The products of these reactions are triose phosphates, which are exported into the cytosol by a specific transporter to be converted to sucrose (Heineke $\&$ Scheibe 2007).

UV-B adversely affects all Calvin cycle enzymes including ribulose-1,5-biphosphate carboxylase/oxygenase (RubisCO). RubisCO is the key enzyme in photosynthesis in algae and C3-plants, as it is responsible for the initial carbon dioxide $\left(\mathrm{CO}_{2}\right)$ fixation. Each RubisCO holoenzyme consists of eight large subunits (LSU, $53 \mathrm{kDa}$ ) and eight small subunits (SSU, $14 \mathrm{kDa}$ ). Both subunit types contain tryptophans (Trp) that are the potential sites for UV-B induced photochemistry. Hence, UV-B causes a decline in RubisCO activity as well as the amounts of both subunits (Xiong \& Day 2001; Lidon et al. 2012; Reboredo \& Lidon 2012; Kataria et al. 2014; Parihar et al. 2017). A previous study attributed the reduction of RubisCO to the lack of nitrogen supply for protein biosynthesis; thus suppression of protein biosynthesis and/or enhancement of protein degradation (Takeuchi et al. 2002).

In conclusion, the decrease in $\mathrm{CO}_{2}$ fixation rates under UV-B can be attributed to several reasons, including thylakoid membranes rupture and photoelectron transport disruption, in addition to the negative impact of the enzymes involved in Calvin cycle. Accordingly, UV-B causes a steep drop in total carbohydrate content either directly by inhibition of enzymes involved in the Calvin cycle, or indirectly by inhibition of the photochemical reactions required to produce NADPH $+\mathrm{H}^{+}$and ATP needed for the Calvin cycle (Prasad et al. 1998; Gwynn-Jones 2001; Bhandari \& Sharma 2006; Ganapathy et al. 2017; Ayash et al. 2018; Kurinjimalar et al. 2019).

\section{DEFENCE MECHANISMS AGAINST UV-B}

Photosynthetic organisms have developed various protective mechanisms against UV-B such as:
Increasing the dermal tissue thickness, which blocks and prevents the harmful UV-B from reaching the photosynthetically active mesophyll (Rozema et al. 1997; Kakani et al. 2003; Qi et al. 2003; Rai \& Agrawal 2017; Neugart \& Schreiner 2018). In addition to increasing wax production and/or the number of trichomes on the surface of some plants (Skaltsa et al. 1994; Barnes et al. 1996; Liakoura et al. 1997; Long et al. 2003; Chen et al. 2020).

\section{Enhancing the concentrations of secondary metabolites}

Phenolic compounds

The phenylpropanoid pathway is ubiquitous in plants for secondary metabolites biosynthesis. It leads to the biosynthesis of various phenolic compounds, which play an important role in plant adaptation to abiotic stresses and survival, not to mention its essential role in plant health and nutrition (Takshak \& Agrawal 2016). These compounds often accumulate within the vacuoles of the upper epidermis leaves and effectively absorb UV radiation thus preventing it from penetrating the leaf mesophyll cells (Xu et al. 2008; Piri et al. 2011; Germ et al. 2015; Surjadinata et al. 2017).

Flavonoids are important natural products with polyphenolic structure. They belong to a group of low-molecular-weight phenolic compounds that are sub-divided into flavones, flavonols, flavanones, flavanonols, flavanols (catechins), anthocyanins, and chalcones (Panche et al. 2016).

It's worth noting that flavonoids are sensitive to light quality, thus their concentrations are higher in plant cells exposed UV radiation (Olsson et al. 1998; Izaguirre et al. 2007; Katerova et al. 2012; Inostroza-Blancheteau et al. 2014; Li et al. 2014; Singh \& Singh, 2014; Suleman et al. 2014; Köhler et al. 2017; Bilodeau et al. 2019; Liu et al. 2020).

Increased flavonoid content under lower exposure correlates well with higher activity of phenylalanine ammonia-lyase (PAL), a key enzyme of flavonoid biosynthesis (Kolb et al. 2001; Kumari et al. 2009; Singh \& Singh, 2014; Suleman et al. 2014; Azarafshan et al. 2020).

Concerning anthocyanins, they are phytopigments responsible for attractive colours in many plant tissues, principally flowers, leaves, and fruits (Vermerris \& Nicholson 2006; Panche et al. 2016). 
Several studies implied the rise in anthocyanins under UV-B stress (Tsormpatsidis et al. 2008; Inostroza-Blancheteau et al. 2014; Singh \& Singh 2014; Reyes-Díaz et al. 2016; Sebastian et al. 2018; Del Valle et al. 2020).

UV-B induces the down-regulation of photosynthesis and other essential processes as mentioned above, thereby increasing the plant's susceptibility to photo-inhibition. It is conceivable that anthocyanins protect the plant cells against photo-damage by reducing the penetration of UV-B to the photosynthetic mesophyll tissue since these pigments concentrate in the epidermal tissues (Steyn et al. 2002; Mahdavian et al. 2008; Goto et al. 2016).

These compounds are potent antioxidants, even though that they are located away from oxidant generation sites in the chloroplast and mitochondria. Many ROS (especially $\mathrm{H}_{2} \mathrm{O}_{2}$ ) may leak to the vacuole during severe stress and then it could be quenched by anthocyanin and other phenolics (Yamasaki 1997; Steyn et al. 2002; Takshak \& Agrawal 2014; Panche et al. 2016; Zhou et al. 2016).

Certain flavonoids, including the more common anthocyanin pigments, have ROS-scavenging capacities up to four times greater than those of vitamin E and C analogues (Rice-Evans et al. 1997; Wang et al. 1997; Hatier \& Gould 2009; Agati et al. 2007), helping to reduce photooxidative damage (Cechin et al. 2012; Tsurunaga et al. 2013).

\section{Carotenoids}

Carotenoids are photosynthetic accessory pigments that absorb visible light between $400-550 \mathrm{~nm}$ (Frank \& Cogdell 1996). They are hydrocarbons containing 40 carbon atoms and are resulting from the polymerization of eight units of isoprene. In general, they are subdivided into two basic classes 1) carotenes (linear lacking oxygen hydrocarbons) such as $\alpha$-carotene, $\beta$-carotene, and lycopene and 2) xanthophylls (oxygenated derivatives of carotenes) such as lutein, violaxanthin, neoxanthin, and zeaxanthin (Mezzomo \& Ferreira 2016; Bhatt \& Patel 2020).

Carotenoids act as protective compounds against photo-oxidative damage of the photosynthetic apparatus and other cell components by quenching the single excited chlorophyll (1Chl*) and possibly a triplet excited chlorophyll $\left(3 \mathrm{Ch} l^{*}\right)$ within reac- tion centres of the photosystems and thermal dissipating of the excess energy, thus preventing the formation of reactive oxygen species. They may also scavenge any evolved singlet-oxygen $\left({ }^{1} \mathrm{O}_{2}\right)$ directly (Müller et al. 2001; Mozzo et al. 2008; Latowski et al. 2011; Bilodeau et al. 2019; Bhatt \& Patel 2020). That is accomplished by carotenes and xanthophylls, but the latter to a greater extent via xanthophyll cycle (the violaxanthin cycle in plants and higher algae and diadinoxanthin cycle in lower algae) (Müller et al. 2001). It is worth noting that some carotenoids, such as astaxanthin, have antioxidant power 500 times higher than vitamin $\mathrm{E}$, which is found in aquatic animals and algae (Mezzomo \& Ferreira 2016).

\section{CONCLUSIONS}

Intensive researches during the last four decades have yielded significant improvement in the understanding of the molecular and physiological background of ultraviolet radiation and its effects on plant physiology. The most sensitive sites for ultraviolet-B (UV-B) radiation in the plant cell are the biomolecules; deoxyribonucleic acid (DNA), proteins, and lipids. On the other hand, UV-B's adverse effects on photosynthesis gained a lot of attention in the last few years, considering the importance of this process for life on Earth. The main targets of UV-B in the photosynthetic apparatus are the thylakoid membranes, which affect both photosystems and the electron carriers attached to them. Plants developed different mechanisms to cope with UV-B stress, including the leaf dermal tissue increment and enhancing the concentrations of secondary metabolites like carotenoids and anthocyanins. Although information about the different effects of UV-B on plant physiology and defence systems have accumulated in the last few decades, further studies are necessary to fully understand the mechanism of these effects.

Acknowledgement: Al-Andalus University for Medical Sciences supported this work. 


\section{REFERENCES}

Agati, G., Matteini, P., Goti, A. and Tattini, M. (2007). Chloroplast-located flavonoids can scavenge singlet oxygen. New Phytologist, 174(1), 77-89.

Agrawal, S.B. (1996). Effect of enhanced ultraviolet-B radiation on growth, pigmentation, nitrogen metabolism and polyamine contents in a cyanobacterium Nostoc muscorum. Biotronics, 25, 1-9.

Alemu, S.T. and Gebre, H. (2020). Impact of Ultraviolet-B radiation based on altitude on photosynthetic efficiency, growth performance and crop yield: a review. Journal of Horticulture and Postharvest Research, 3(2), 285-296.

Allorent, G., Lefebvre-Legendre, L., Chappuis, R., Kuntz, M., Truong, T., Niyogi, K., Ulm, R. and Goldschmidt-Clermont, M. (2016). UV-B photoreceptor-mediated protection of the photosynthetic machinery in Chlamydomonas reinhardtii. Proceedings of the National Academy of Sciences, 113(51), 14864-14869.

Alves, L. and Deschamps, C. (2019). Radiation levels of UV-A and UV-B on growth parameters and coumarin content in guaco. Ciência Rural, 49(6), e20190042. DOI: $10.1590 / 0103-8478 \mathrm{cr} 20190042$.

Ayash, A., Mohammad, I. and Nassour, R. (2018). The role of polyethylene films in reducing the harmful effects of UV radiation on the productivity of Euglena gracilis. SSRG International Journal of Agriculture \& Environmental Science (IJAES), 5(2), 45-49.

Ayash, A., Mohammad, I. and Nassour, R. (2017). The effect of ultraviolet radiation on chlorophyll in Chlamydomonas reinhardtii. SSRG International Journal of Agriculture \& Environmental Science (IJAES), 4(6), 23-27.

Azarafshan, M., Peyvandi, M., Abbaspour, H., Noormohammadi, Z. and Majd, A. (2020). The effects of UV-B radiation on genetic and biochemical changes of Pelargonium graveolens L/Her. Physiology and Molecular Biology of Plants, 26(3), 605-616.

Babele, P.K., Singh, G., Tyagi, M.B., Sinha, R.S. and Kumar, A. (2012). Ultraviolet-B radiation effects on cyanobacteria and the role of sunscreen pigments in its protection. Phykos, $42(2), 1-13$

Bacelar, E., Moutinho-Pereira, J., Ferreira, H. and Correia, C. (2015). Enhanced ultraviolet-B radiation affect growth, yield and physiological processes on triticale plants. Procedia Environmental Sciences, 29, 219-220.

Ball, W.T., Alsing, J., Mortlock, D.J., Staehelin, J., Haigh, J.D., Peter, T., Tummon, F., Stübi, R., Stenke, A., Anderson, J., Bourassa, A., Davis, S.M., Degenstein, D., Frith, S., Froidevaux, L., Roth, C., Sofieva, V., Wang, R., Wild, J., Yu, P., Ziemke, J.R. and Rozanov, E.V. (2018). Evidence for a continuous decline in lower stratospheric ozone offsetting ozone layer recovery. Atmospheric Chemistry and Physics, $18,1379-1394$.

Barber, J. (2014). Photosystem II: Its function, structure, and implications for artificial photosynthesis. Biochemistry (Moscow), 79(3), 185-196.

Barnes, J.D., Percy, K.E., Paul, N.D., Jones, P., Mclaughlin, C.K., Mullineaux, P.M., Creissen, G. and Wellburn, A.R. (1996). The influence of UV-B radiation on the physicochemical nature of tobacco (Nicotiana tabacum L.) leaf surfaces. Journal of Experimental Botany, 47(294), 99-109.

Bassman, J.H., Edwards, G.E. and Robberecht, R. (2003). Photosynthesis and growth in seedlings of five forest tree spe- cies with contrasting leaf anatomy subjected to supplemental UV-B radiation. Forest Science, 49, 176-187.

Bassman, J.H. and Robberecht, R. (2006). Growth and gas exchange in field-grown and greenhouse-grown Quercus rubra following three years of exposure to enhanced UV-B radiation. Tree Physiology, 26, 1153-1163.

Beardall, J. and Raven, J.A. (2004). The potential effects of global climate change on microalgal photosynthesis, growth and ecology. Phycologia, 43(1), 26-40.

Bergo, E., Segalla, A., Giacometti, G.M., Tarantino, D., Soave, C., Andreucci, F. and Barbato, R. (2003). Role of visible light in the recovery of photosystem II structure and function from ultraviolet-B stress in higher plants. Journal of Experimental Botany, 54(388), 1665-1673.

Bhandari, R. and Sharma, P.K. (2006). Effect of UV-B on photosynthesis, membrane lipids and MAAs in marine cyanobacterium Phormidium corium (Agardh) Gomont. Indian Journal of Experimental Biology, 44, 330-335.

Bhatt, T. and Patel, K. (2020). Carotenoids: Potent to prevent diseases review. Natural Products and Bioprospecting, 10, $109-117$.

Bhattacharjee, S. (2019). ROS and sxidative stress: Origin and implication. In Bhattacharjee, S. (Ed.) Reactive oxygen species in plant biology. India: Springer, pp. 1-31.

Bidlack, J.E. and Jansky, S.H. (2018). Cells. In Bidlack, J.E. and Jansky, S.H. (Eds.) Stern's Introductory Plant Biology. $14^{\text {th }}$ ed. New York (NY): McGraw-Hill, pp. 29-52.

Bilodeau, S.E., Wu, B.S., Rufyikiri, A.S., Macpherson, S. and Lefsrud, M. (2019). An update on plant photobiology and implications for cannabis production. Frontiers in Plant Science, 10, 1-15.

Booij-James, I.S., Dube, S.K., Jansen, M.A.K., Edelman, M. and Mattoo, A.K. (2000). Ultraviolet-B radiation impacts light-mediated turnover of the photosystem II reaction center heterodimer in Arabidopsis mutants altered in phenolic metabolism. Physiology, 124, 1275-1283.

Bornman, J.F. (1989). New trends in photobiology (invited review): Target sites of UV-B radiation in photosynthesis of higher plants. Journal of Photochemistry and Photobiology B: Biology, 4, 145-158.

Buma, A.G.J., Zemmelink, H.J., Sjollema, K. and Gieskes, W.W.C. (1996). UVB radiation modifies protein and photosynthetic pigment content, volume and ultrastructure marine diatoms. Marine Ecology Progress Series, 142, 47-54.

Cai, W., Gao, X., Hu, J., Chen, L., Li, X., Liu, Y. and Wang, G. (2016). UV-B radiation inhibits the photosynthetic electron transport chain in Chlamydomonas reinhardtii. Pakistan Journal of Botany, 48(6), 2587-2593.

Caldwell, M.M., Bornman, J.F., Ballar, C.L., Flint, S.D. and Kulandaivelu, G. (2007). Terrestrial ecosystems, increased solar ultraviolet radiation, and interactions with other climate change factors. Photochemical and Photobiological Sciences, 6, 252-266.

Caldwell, M.M. and Flint, S.D. (1994). Stratospheric ozone reduction, solar UV-B radiation and terrestrial ecosystems. Climatic Change, 28, 375-394.

Castenholz, R.W. and Garcia-Pichel, F. (2012). Cyanobacterial responses to UV radiation. In Whitton, B.A. (Ed.) Ecology of Cyanobacteria II: Their Diversity in Space and Time. Netherlands: Springer, pp. 481-499.

Cechin, I., Fumis, T.F. and Dokkedal, A.L. (2007). Growth and physiological responses of sunflower plants exposed to ultraviolet-B radiation. Ciência Rural, Santa Maria, 37(1), $85-90$.

Cechin, I., Gonzalez, G.C., Corniani, N. and Fátima, F.T. (2018). The sensitivity of sunflower (Helianthus annuus L.) plants to UV-B radiation is altered by nitrogen status. Ciên- 
cia Rural, 48(2). DOI: 10.1590/0103-8478cr20170369.

Cechin, I., Rocha, V.J. and Fumis, T.F. (2012). Sensitivity of yellow passion fruit to ultraviolet-B radiation. Pesquisa Agropecuária Brasileira, 47(10), 1422-1427.

Chen, Z., Gao, W., Reddy, K.R., Chen, M., Taduri, S., Meyers, S.L. and Shankle, M.W. (2020). Ultraviolet (UV) B effects on growth and yield of three contrasting sweet potato cultivars. Photosynthetica, 58(1), 37-44.

Chipperfield, M.P., Bekki, S., Dhomse, S., Harris, N.R.P., Hassler, B., Hossaini, R., Steinbrecht, W., Thiéblemont, R. and Weber, M. (2017). Detecting recovery of the stratospheric ozone layer. Nature, 549, 211-218. DOI:10.1038/nature23681.

Del Valle, J.C., Buide, M.L., Whittall, J.B., Valladares, F. and Narbona, E. (2020). UV radiation increases phenolic compound protection but decreases reproduction in Silene littorea. PLOS ONE, 15(6): e0231611. DOI:10.1371/journal. pone. 0231611.

Dmitrieva, V.A., Tyutereva, E.V. and Voitsekhovskaja, O.V. (2020). Singlet oxygen in plants: Generation, detection, and signaling roles. International Journal of Molecular Sciences, 21, 3237. DOI:10.3390/ijms21093237.

Draper, C.K. and Hays, J.B. (2000). Replication of chloroplast, mitochondrial and nuclear DNA during growth of unirradiated and UVB-irradiated Arabidopsis leaves. The Plant Journal, 12(2), 255-265.

Eerden, F.J.V., Melo, M.N., Frederix, P.W.J.M., Periole, X. and Marrink, S.J. (2017). Exchange pathways of plastoquinone and plastoquinol in the photosystem II complex. Nature Communications, 8, article number 15214. DOI:10.1038/ ncomms 15214.

Fina, J., Casadevall, R., Abdelgawad, H., Prinsen, E., Markakis, M.N., Beemster, G.T.S. and Casati, P. (2017). UV-B inhibits leaf growth through changes in growth regulating factors and gibberellin levels. Plant Physiology, 174, 1110-1126.

Frank, H.A. and Cogdell, R.J. (1996). Carotenoids in photosynthesis. Photochemistry and Photobiology, 63(3), 257-264.

Frohnmeyer, H. and Staiger, D. (2003). Ultraviolet-B radiation-mediated responses in plants. Balancing damage and protection. Plant Physiology, 133, 1420-1428.

Fu, G. and Shen, Z.X. (2017). Effects of enhanced UV-B radiation on plant physiology and growth on the Tibetan Plateau: a meta-analysis. Acta Physiologiae Plantarum, 39, article number 85. DOI:10.1007/s11738-017-2387-8.

Ganapathy, K., Chidambaram, K., Janarthanan, R. and Ramasamy, R. (2017). Effect of UV-B radiation on growth, photosynthetic activity and metabolic activities of Chlorella vulgaris. Research and Reviews: Journal of Microbiology and Biotechnology, 6(2), 53-60.

Germ, M., Spahić, I. and Gaberščik, A. (2015). Morphological, biochemical and physiological responses of Indian cress (Tropaeolum majus) to elevated UV-B radiation. Periodicum Biologorum, 117(3), 357-364.

Gill, S.S., Anjum, N.A., Gill, R., Jha, M. and Tuteja, N. (2015). DNA damage and repair in plants under ultraviolet and ionizing radiations. Hindawi Publishing Corporation, 2015, Article ID 250158. DOI:10.1155/2015/250158.

Golaszewska, K.Z., Upadhyaya, M.K. and Golaszewski, J. (2003). The effect of UV-B radiation on plant growth and development. Plant, Soil and Environment, 49(3), 135-140.

Goto, E., Hayashi, K., Furuyama, S., Hikosaka, S. and Ishigami, Y. (2016). Effect of UV light on phytochemical accumulation and expression of anthocyanin biosynthesis genes in red leaf lettuce. ISHS Acta Horticulturae, 1134, 179-186. DOI:10.17660/ActaHortic.2016.1134.24.

Gupta, R., Bhadauriya, P., Chauhan, V.S. and Bisen, B.S. (2008). Impact of UV-B radiation on thylakoid membrane and fatty acid profile of Spirulina platensis. Current Microbiology, 56, 156-161.

Gwynn-Jones, D. (2001). Short-term impacts of enhanced UV-B radiation on photo-assimilate allocation and metabolism: A possible interpretation for time-dependent inhibition of growth. Plant Ecology, 154, 65-73.

Häder, D.P. (1991). Effects of enhanced solar ultraviolet radiation on aquatic ecosystems. In Lenci, F., Ghetti, F., Colombetti, G., Häder, D.P., Song, P.S. (Eds.) Biophysics of photoreceptors and photomovements in microorganisms. New York (NY): Plenum Press, pp. 157-172.

Hatier, J.H.B. and Gould, K.S. (2009). Anthocyanin function in vegetative organs. In Gould, K., Davies, K., Winefield, C. (Eds.) Anthocyanins: biosynthesis, functions, and applications. New York (NY): Springer, pp. 1-19.

Heineke, D. and Scheibe, R. (2007). Photosynthesis: The Calvin cycle. Chichester: John Wiley \& Sons. DOI: 10.1002/9780470015902.a0001291.pub2.

Hideg, E., Jansen, M.A.K. and Strid, A.K. (2013). UV-B exposure, ROS, and stress: inseparable companions or loosely linked associates? Trends Plant Science, 18(2), 107-115. DOI: $10.1016 /$ j.tplants.2012.09.003.

Hollosy, F. (2002). Effects of ultraviolet radiation on plant cell. Micron, 33(2), 179-197. DOI: 10.1016/S09684328(01)00011-7.

Holzinger, A. and Lütz, C. (2006). Algae and UV irradiation: Effects on ultrastructure and related metabolic functions. $\mathrm{Mi}$ cron, 37(3), 190-207. DOI:10.1016/j.micron.2005.10.015.

Hopkins, L., Bond, M.A. and Tobin, A.K. (2002). Ultraviolet-B radiation reduces the rates of cell division and elongation in the primary leaf of wheat (Triticum aestivum L. cv Maris Huntsman). Plant, Cell and Environment, 25, 617-624.

Huang, H., Ullah, F., Zhou, D.X., Yi, M. and Zhao, Y. (2019). Mechanisms of ROS regulation of plant development and stress responses. Frontiers in Plant Science, 10, 800. DOI: 10.3389/fpls.2019.00800.

Inostroza-Blancheteau, C., Reyes-Díaz, M., Arellano, A., Latsague, M., Acevedo, P., Loyola, R., Arce-Johnson, P. and Alberdi, M. (2014). Effects of UV-B radiation on anatomical characteristics, phenolic compounds and gene expression of the phenylpropanoid pathway in highbush blueberry leaves. Plant Physiology and Biochemistry, 85, 85-95.

Izaguirre, M.M., Mazza, C.A., Svatoš, A., Baldwin, I.T. and Ballare, C.L. (2007). Solar ultraviolet-B radiation and insect herbivory trigger partially overlapping phenolic responses in Nicotiana attenuata and Nicotiana longiflora. Annals of Botany, 99, 103-109.

Jiang, L., Wang, Y., Björn, L.O. and Li, S. (2011). UV-B-induced DNA damage mediates expression changes of cell cycle regulatory genes in Arabidopsis root tips. Planta, 233(4), 831-841.

Jithesh, M.N., Prashanth, S.R., Sivaprakash, K.R. and Parida, A.K. (2006). Antioxidative response mechanisms in halophytes: Their role in stress defence. Journal of Genetics, $85(3), 237-254$.

Juan, Y., Xuexi, T., Peiyu, Z., Jiyuan, T. and Shuaglin, D. (2005). Physiological and ultrastructural changes of chlorella sp. induced by UV-B radiation. Progress in Natural Science, 15(8), 678-683.

Juozaityte, R., Ramaškeviciene, A., Sliesaravicius, A., Burbulis, N., Kupriene, R., Liakas, V. and Blinstrubiene, A. (2008). Effects of UVB radiation on photosynthesis pigment system and growth of pea (Pisum sativum L.). Sodininkyste Ir Daržininkyste, 27(2), 179-186.

Kakani, V.G., Reddy, K.R., Zhao, D. and Sailaja, K. (2003). Field crop responses to ultraviolet-B radiation: a review. Agricultural and Forest Meteorology, 120, 191-218. 
Kataria, S., Jajoo, A. and Guruprasad, K.N. (2014). Impact of increasing Ultraviolet-B (UV-B) radiation on photosynthetic processes. Journal of Photochemistry and Photobiology B: Biology, 137, 55-66.

Katerova, Z., Todorova, D., Tasheva, K. and Sergiev, I. (2012). Influence of ultraviolet radiation on plant secondary metabolite production. Genetics and plant physiology, 2(3-4), $113-144$.

Köhler, H., Contreras, R.A., Pizarro, M., Cortés-Antíquera, R. and Zúñiga, G.E. (2017). Antioxidant responses induced by UVB radiation in Deschampsia antarctica Desv. Frontiers in Plant Science, 8, 1-10.

Kolb, C.A., Käser, M.A., Kopecky, J., Zotz, G., Riederer, M. and Pfündel, E.E. 2001. Effects of natural intensities of visible and ultraviolet radiation on epidermal ultraviolet screening and photosynthesis in grape leaves. Plant Physiology, $127,863-875$.

Kramer, G.F., Norman, H.A., Krizek, D.T. and Mirecki, R.M. (1991). Influence of UV-B radiation on polyamines, lipid peroxidation and membrane lipids in cucumber. Phytochemistry, 30(7), 2101-2108.

Kumar, V., Nanda, M., Kumar, S. and Chauhan, P.K. (2018). The effects of ultraviolet radiation on growth, biomass, lipid accumulation and biodiesel properties of microalgae. Energy Sources, Part A: Recovery, Utilization, and Environmental Effects, 40(7), 787-793. DOI:10.1080/ 15567036.2018.1463310.

Kumari, R., Singh, S. and Agrawal, S.B. (2009). Effects of supplemental ultraviolet-B radiation on growth and physiology of Acorus calamus L. (SWEET FLAG). Acta Biologica Cracoviensia Series Botanica, 51(2), 19-27.

Kurinjimalar, C., Kavitha, G., Thevanathan, R., Kulandaivelu, G. and Rengasamy, R. (2019). Impact of ultraviolet-B radiation on growth and biochemical composition of Botryococcus braunii Kutz. Current Science, 116(1), 89-95.

Kurisu, G., Zhang, H., Smith, J.L., William, A. and Cramer, W.A. (2003). Structure of the cytochrome $\mathrm{b}_{6} \mathrm{f}$ complex of oxygenic photosynthesis: Tuning the cavity. Science, 302, $1009-1014$.

Latowski, D., Kuczyńska, P. and Strzalka, K. (2011). Xanthophyll cycle - a mechanism protecting plants against oxidative stress. Redox Report, 16(2), 78-90.

Li, F.M., Lu, Z.G. and Yue, M. (2014). Analysis of photosynthetic characteristics and UV-B absorbing compounds in mung bean using UV-B and red LED radiation. Journal of Analytical Methods in Chemistry, 2014, 1-5.

Li, N., Teranishi, M., Yamaguchi, H., Matsushita, T., Watahiki, M.K., Tsuge, T., Li, S., Hidema, J. (2015). UV-B-induced CPD photolyase gene expression is regulated by UVR8-dependent and -independent pathways in Arabidopsis. Plant Cell Physiology, 56(10), 2014-2023.

Liakoura, V., Stefanou, M., Manetas, Y., Cholevas, C. and Karabourniotis, G. (1997). Trichome density and its UV-B protective potential are affected by shading and leaf position on the canopy. Environmental and Experimental Botany, 38, $223-229$

Lidon, F.C. and Ramalho, J.C. (2011). Impact of UV-B irradiation on photosynthetic performance and chloroplast membrane components in Oryza sativa L. Journal of Photochemistry and Photobiology B: Biology, 104, 457-466.

Lidon, F.J.C., Reboredo, F.H., Leltao, A.E., Silva, M.M.A., Duarte, P.D. and Ramalho, J.C. 2012. Impact of UV-B radiation on photosynthesis- an overview. Emirates Journal of Food \& Agriculture, 24(6), 546-556.

Liu, Y., Liu, J., Abozeid, A., Wu, K.X., Guo, X.R., Mu, L.Q. and Tang, Z.H. 2020. UV-B radiation largely promoted the transformation of primary metabolites to phenols in Astra- galus mongholicus seedlings. Biomolecules, 10, 504. DOI: 10.3390/biom10040504.

Long, L.M., Patel, H.P., Cory, W.C. and Stapleton, A.E. (2003). The maize epicuticular wax layer provides UV protection. Functional Plant Biology, 30, 75-81.

Madronich, S., Mckenzie, R.L., Björn, L.O. and Caldwell, M.M. 1998. Changes in biologically active ultraviolet radiation reaching the Earth's surface. Journal of Photochemistry and Photobiology B: Biology, 46, 5-19.

Mahdavian, K., Ghorbanli, M. and Kalantari, K.M. (2008). The effects of ultraviolet radiation on the contents of chlorophyll, flavonoid, anthocyanin and proline in Capsicum annuum L. Turkish Journal of Botany, 32, 25-33.

Mandi, S.S. (2016). Natural Ultraviolet Radiation. In Mandi, S.S. (Ed.) Natural UV radiation in enhancing survival value and quality of plants. India: Springer, pp. 1-22.

Marwood, C.A. and Greenberg, B.M. (1996). Effect of supplementary UVB radiation on chlorophyll synthesis and accumulation of photosystems during chloroplast development in Spirodela oligorrhiza. Photochemistry and Photobiology, 64(4), 664-670.

Melis, A., Nemson, J.A. and Harrison, M.A. 1992. Damage to functional components and partial degradation of Photosystem II reaction center proteins upon chloroplast exposure to ultraviolet-B radiation. Biochimica et Biophysica Acta, $1100,312-320$.

Mezzomo, N. and Ferreira, S.R.S. (2016). Carotenoids functionality, sources, and processing by supercritical technology: A review. Journal of Chemistry, 2016, Article ID 3164312. DOI: $10.1155 / 2016 / 3164312$.

Mhamdi, A. and Breusegem, F.V. (2018). Reactive oxygen species in plant development. Development, 145(15), dev164376. DOI:10.1242/dev.164376.

Moorthy, P. and Kathiresan, K. (1998). UV-B induced alterations in composition of thylakoid membrane and amino acids in leaves of Rhizophora apiculate Blume. Photosynthetica, 35(3), 321-328.

Mosadegh, H., Trivellini, A., Lucchesini, M., Ferrante, A., Maggini, R., Vernieri, P. and Sodi, A.M. (2019). UV-B physiological changes under conditions of distress and eustress in sweet basil. Plants, 8, 396. DOI: 10.3390/plants8100396.

Mozzo, M., Dall'osto, L., Hienerwadel, R., Bassi, R. and Croce, R. (2008). Photoprotection in the antenna complexes of photosystem II: role of individual xanthophylls in chlorophyll triplet quenching. The Journal of Biological Chemistry, 283(10), 6184-6192.

Müller, P., Li, X.P. and Niyogi, K.K. (2001). Non-photochemical quenching. A response to excess light energy. Plant Physiology, 125, 1558-1566.

Najafpour, M.M. and Govindjee, G. (2011). Oxygen evolving complex in Photosystem II: Better than excellent. Dalton Transactions, 40, 9076-9084. DOI: 10.1039/c1dt10746a.

Nasibi, F. and M-Kalantari, K.H. (2005). The effects of UVA, UV-B and UV-C on protein and ascorbate content, lipid peroxidation and biosynthesis of screening compounds in Brassica napus. Iranian Journal of Science and Technology, Transaction A, 29(A1), 39-48.

Nawkar, G.M., Maibam, P., Park, J.H., Sahi, V.P., Lee, S.Y. and Kang, C.H. (2013). UV-induced cell death in plants. International Journal of Molecular Sciences, 14, 1608-1628.

Neugart, S. and Schreiner, M. (2018). UVB and UVA as eustressors in horticultural and agricultural crops. Scientia Horticulturae, 234, 370-381.

Niyogi, K.K., Wolosiuk, R.A. and Malkin, R. (2015). Photosynthesis. In Buchanan, B.B., Gruissem, W., Jones, R.L. (Eds.) Biochemistry and molecular biology of plants. India: John Wiley \& Sons, pp. 508-566. 
Noaman, N.H. (2007). Ultraviolet-B irradiation alters amino acids, proteins, fatty acids contents and enzyme activities of Synechococcus leopoliensis. International Journal of Botany, 3, 109-113.

Nogués, S., Allen, D.J., Morison, J.I.L. and Baker, N.R. (1998). Ultraviolet-B radiation effects on water relations, leaf development, and photosynthesis in droughted pea plants. In Plant Physiology, 117, 173-181.

Olsson, L.C., Veit, M., Weissenböck, G. and Bornman, J.F. (1998). Differential flavonoid response to enhanced UV-B radiation in Brassica napus. Phytochemistry, 49(4), $1021-1028$.

Panche, A.N., Diwan, A.D. and Chandra, S.R. (2016). Flavonoids: an overview. Journal of Nutritional Science, 5(47), $1-15$.

Parani, K. and Vidhya, K. (2018). Impact of UV-B irradiation on two different Ferns. Bioscience Discovery, 9(1), 25-28.

Parihar, P., Singh, R., Singh, S., Singh, M.P.V.V.B., Singh, V.P. and Prasad, S.M. (2017). Ultraviolet radiation targets in the cellular system: Current status and future directions. In Singh, V.P., Singh, S., Prasad, S.M., Parihar, P. (Eds.) UV-B radiation: From environmental stressor to regulator of plant growth. $1^{\text {st }}$ ed. India: John Wiley and Sons, pp. 155-174.

Pérez, G., Doldán, S., Borsani, O. and Irisarri, P. (2012). Differential response to moderate UV-B irradiation of two heterocystous cyanobacteria isolated from a temperate rice field. Advances in Microbiology, 2, 37-47.

Pessoa, M.F. (2012). Harmful effects of UV radiation in Algae and aquatic macrophytes - A review. Emirates Journal of Food Agriculture, 24(6), 510-526.

Pfeifer, G.P. and Besaratinia, A. (2012). UV wavelength-dependent DNA damage and human non-melanoma and melanoma skin cancer. Photochemical and Photobiological Sciences, 11, 90-97.

Piri, E., Babaeian, M., Tavassoli, A. and Esmaeilian, Y. (2011). Effects of UV irradiation on plants. African Journal of Microbiology Research, 5(14), 1710-1716.

Pradhan, M.K., Joshi, P.N., Nair, J.S., Ramaswamy, N.K., Iyer, R.K., Biswal, B. and Biswal, U.C. (2006). UV-B exposure enhances senescence of wheat leaves: modulation by photosynthetically active radiation. Radiation and Environment Biophysics, 45, 221-229.

Prasad, V., Kumar, A. and Kumar, H.D. (1998). Effects of UV-B on certain metabolic processes of the green alga Chlorella vulgaris. International Journal of Environmental Studies, 55(1-2), 129-140.

Qi, Y., Bai, S. and Heiler, G.M. (2003). Changes in ultraviolet-B and visible optical properties and absorbing pigment concentrations in pecan leaves during a growing season. Agricultural and Forest Meteorology, 120(1-4), 229-240.

Rai, K. and Agrawal, S.B. (2017). Effects of UV-B radiation on morphological, physiological and biochemical aspects of plants: an overview. Journal of Scientific Research, 61, $87-113$.

Rastogi, R.P., Sinha, R.P., Moh, S.H., Lee, T.K., Kottuparambil, S., Kim, Y.J., Rhee, J.S., Choi, E.M., Brown, M.T., Häder, D.P. and Han, T. (2014). Ultraviolet radiation and cyanobacteria. Journal of Photochemistry and Photobiology B: Biology, 141, 154-169.

Reboredo, F. and Lidon, F.J.C. (2012). UV-B radiation effects on terrestrial plants - A perspective. Emirates Journal of Food and Agriculture, 24(6), 502-509.

Reddy, K.R., Singh, S.K., Koti, S., Kakani, V.G., Zhao, D., Gao, W. and Reddy, V.R. (2013). Quantifying the effects of corn growth and physiological responses to ultraviolet-B radiation for modeling. Agronomy Journal, 105(5), 1367-1377.

Ren, J., Yao, Y., Yang, Y., Korpelainen, H., Junttila, O. and Li,
C. (2006). Growth and physiological responses to supplemental UV-B radiation of two contrasting poplar species. Tree Physiology, 26, 665-672.

Rensen, J.J.S., Vredenberg, W.J. and Rodrigues, G.C. (2007). Time sequence of the damage to the acceptor and donor sides of photosystem II by UV-B radiation as evaluated by chlorophyll a fluorescence. Photosynthesis Research, 94, 291-297.

Reyes, T.H., Scartazza, A., Castagna, A., Cosio, E.G., Ranieri, A., and Guglielminetti, L. (2018). Physiological effects of short acute UVB treatments in Chenopodium quinoa Willd. Scientific Reports, 8, Article number: 371. DOI: 10.1038/ s41598-017-18710-2

Reyes, T.H., Scartazza, A., Pompeiano, A. and Guglielminetti, L. 2019. Physiological responses of Lepidium meyenii plants to ultraviolet-B radiation challenge. BMC Plant Biology, 19, Article number: 186. DOI:10.1186/s12870-0191755-5.

Reyes-Díaz, M., Meriño-Gergichevich, C., Inostroza-Blancheteau, C., Latsague, M., Acevedo, P. and Alberdi, M. 2016: Anatomical, physiological, and biochemical traits involved in the UV-B radiation response in highbush blueberry. $B i$ ologia Plantarum, 60, 355-366.

Rice-Evans, C.A., Miller, N. and Paganga, G. (1997). Antioxidant properties of phenolic compounds. Trends Plant Science, 2(4), 152-159.

Robson, T.M., Aphalo, P.J., Banaś, A.K., Barnes, P.W., Craig, C., Brelsford, C.C., Jenkins, G.I., Kotilainen, T.K., Labuz, J., Martínez-Abaigar, J., Morales, L.O., Neugart, S., Pieristè, M., Rai, N., Vandenbussche, F. and Jansen, M.A.K. (2019). A perspective on ecologically relevant plant-UV research and its practical application. Photochemical \& Photobiological Sciences, 18, 970-988. DOI: 10.1039/c8pp00526e.

Roleda, M.Y., Wiencke, C. and Lüder, U.H. 2006. UV-absorbing compounds, photosynthesis, DNA damage, and germination in zoospores of arctic Saccorhiza dermatodea. Journal of Experimental Botany, 57(14), 3847-3856.

Rozema, J., Chardonnens, A., Tosserams, M., Hafkenscheid, R. and Bruijnzeel, S. 1997. Leaf thickness and UV-B absorbing pigments of plants in relation to an elevational gradient along the Blue Mountains, Jamaica. Plant Ecology, 128, $151-159$.

Sakalauskaite, J., Viskelis, P., Dambrauskiene, E., Sakalauskiene, S., Samuoliene, G.A., Duchovskis, P. and Urbonaviciene, D. 2013. The effects of different UV-B radiation intensities on morphological and biochemical characteristics in Ocimum basilicum L. Journal of the Science of Food and Agriculture, 93, 1266-1271.

Salama, H.M.H., Al Watban, A.A. and Al-Fughom, A.T. (2011). Effect of ultraviolet radiation on chlorophyll, carotenoid, protein and proline contents of some annual desert plants. Saudi Journal of Biological Sciences, 18, 79-86.

Sebastian, A., Kumari, R., Kiran, B.R. and Prasad, M.N.V. (2018). Ultraviolet B induced bioactive changes of enzymatic and non-enzymatic antioxidants and lipids in Trigonella foenum-graecum L. (Fenugreek). The EuroBiotech Journal, 2(1), 64-71.

Jansen, M.A.K. (2017). Ultraviolet-B Radiation: Stressor and Regulatory Signal. In Shabala, S. (Ed.) Plant stress physiology. $2^{\text {nd }}$ ed. India: CAB international, pp. 253-278.

Sharma, P., Jha, A.B., Dubey, R.S. and Pessarakli, M. (2014). Reactive oxygen species generation, hazards, and defense mechanisms in plants under environmental (abiotic and biotic) stress conditions. In Pessarakli, M. (Ed.) Handbook of Plant and Crop Physiology. $3^{\text {rd }}$ ed. USA: Taylor and Francis Group, 1018, pp. 509-547.

Sicora, C., Máté, Z. and Vass, I. 2003. The interaction of visible 
and UV-B light during photodamage and repair of Photosystem II. Photosynthesis Research, 75, 127-137.

Sicora, C., Szilárd, A., Sass, L., Turcsányi, E., Máté, Z. and Vass, I. 2006. UV-B and UV-A radiation effects on photosynthesis at the molecular level. In Ghetti, F., Checcucci, G., Bornman, J.F. (Eds.) Environmental UV radiation: impact on ecosystems and human health and predictive models. Netherlands: Springer, pp. 121-135.

Singh, J. and Singh, R.P. (2014). Adverse effects of UV-B radiation on plants growing at Schirmacher Oasis, East Antarctica. Toxicology International, 21(1), 101-106.

Sinha, R.P., Klisch, M., Gröniger, A. and Häder, D.P. (2001). Responses of aquatic algae and cyanobacteria to solar UVB. Plant Ecology, 154, 221-236.

Sivasakthivel, T. and Reddy, K.K.S.K. (2011). Ozone layer depletion and its effects: A review. International Journal of Environmental Science and Development, 2(1), 30-37.

Skaltsa, H., Verykokidou, E., Harvala, C., Karabourniotis, G. and Manetas, J. (1994). UV-B protective potential and flavonoid content of leaf hairs of Quercus Ilex. Phytochemitstry, 37(4), 987-990.

Sliney, D.H. and Chaney, E. 2006. Basic concepts of radiation. In Ghetti, F., Checcucci, G., Bornman, J.F. (Eds.) Environmental UV radiation: Impact on ecosystems and human health and predictive models. Netherlands: Springer, pp. $5-23$.

Sreelakshmi, T. and Raza, S.H. (2014). Effect of UV-A radiation on photosynthetic pigments of selected crop plants. Biolife, 2(1), 381-386

Steyn, W.J., Wand, S.J.E., Holcroft, D.M. and Jacobs, G. (2002). Anthocyanins in vegetative tissues: a proposed unified function in photoprotection. New Phytologist, 155, $349-361$.

Suchar, V.A. and Robberecht, R. (2016). Integration and scaling of UV-B radiation effects on plants: from molecular interactions to whole plant responses. Ecology and Evolution, 6(14), 4866-4884.

Suleman, P., Redha, A., Afzal, M. and Al-Hasan, R. (2014). Effects of UV-B on photosynthetic parameters, lipid peroxidation, flavonoids and growth traits of Conocarpus lancifolius (engl.). American Journal of Agricultural and Biological Sciences, 9(1), 55-63.

Surjadinata, B.B., Jacobo-Velázquez, D.A. and Cisneros-Zevallos, L. (2017). UVA, UVB and UVC light enhances the biosynthesis of phenolic antioxidants in fresh-cut carrot through a synergistic effect with wounding. Molecules, 22(4), 668. DOI: 10.3390/molecules22040668.

Szilárd, A., Sass, L., Deák, Z. and Vass, I. (2007). The sensitivity of photosystem II to damage by UV-B radiation depends on the oxidation state of the water-splitting complex. Biochimica et Biophysica Acta, 1767, 876-882.

Sztatelman, O., Grzyb, J., Gabryś, H. and Banaś, A.K. (2015). The effect of UV-B on Arabidopsis leaves depends on light conditions after treatment. BMC Plant Biology, 15, Article number: 281. DOI: 10.1186/s12870-015-0667-2.

Taiz, L. and Zeiger, E. (2010). Photosynthesis: The Light Reactions. In Taiz, L. and Zeiger, E. (Eds.) Plant physiology. $5^{\text {th }}$ ed., New York (NY), USA: Sinauer Associates, pp. $111-143$.

Takahashi, S., Kojo, K., Kutsuna, N., Endo, M., Toki, S., Isoda, H. and Haseza, W.A.S. 2015. Differential responses to highand low-dose ultraviolet-B stress in tobacco bright yellow-2 cells. Frontiers in Plant Science, 6:254. DOI: 10.3389/ fpls.2015.00254.

Takeuchi, A., Yamaguchi, T., Hidema, J., Strid, A. and Kumagai, T. (2002). Changes in synthesis and degradation of RubisCO and LHCII with leaf age in rice (Oryza sativa L.) growing under supplementary UV-B radiation. Plant, Cell and Environment, 25, 695-706.

Takshak, S. and Agrawal, S.B. (2014). Effect of ultraviolet-B radiation on biomass production, lipid peroxidation, reactive oxygen species, and antioxidants in Withania somnifera. Biologia Plantarum, 58, 328-334.

Takshak, S. and Agrawal, S.B. (2016). Ultraviolet-B radiation: A potent elicitor of phenylpropanoid pathway compounds. Journal of Scientific Research, 60, 79-96.

Tilbrook, K., Dubois, M., Crocco, C.D., Yin, R., Chappuis, R., Allorent, G., Schmid-Siegert, E., Goldschmidt-Clermont, M. and Ulm, R. 2016. UV-B perception and acclimation in Chlamydomonas reinhardtii. Plant Cell, 28(4), 966-983.

Tsormpatsidis, E., Henbest, R.G.C., Davis, F.J., Battey, N.H., Hadley, P. and Wagstaffe, A. (2008). UV irradiance as a major influence on growth, development and secondary products of commercial importance in Lollo Rosso lettuce 'Revolution' grown under polyethylene films. Environmental and Experimental Botany, 63, 232-239.

Tsurunaga, Y., Takahashi, T., Katsube, T., Kudo, A., Kuramitsu, O., Ishiwata, M. and Matsumoto, S. (2013). Effects of UV-B irradiation on the levels of anthocyanin, rutin and radical scavenging activity of buckwheat sprouts. Food Chemistry, 141, 552-556.

Vass, I., Sass, L., Spetea, C., Bakou, A., Ghanotakis, D.F. and Petrouleas, V. (1996). UV-B induced inhibition of photosystem II electron transport studied by EPR and chlorophyll fluorescence. Impairment of donor and acceptor side components. Biochemistry, 35, 8964-8973.

Vass, I., Szilárd, A. and Sicora, C. (2005). Adverse effects of UV-B light on the structure and function of the photosynthetic apparatus. In Pessarakli, M. (Ed.) Handbook of Photosynthesis. New York (NY): CRC Press, pp. 814-830.

Vass, I. (2012). Molecular mechanisms of photodamage in the Photosystem II complex. Biochimica et Biophysica Acta, 1817, 209-217.

Vermerris, W. and Nicholson, R. (2006). Families of phenolic compounds and Means of classification. In Vermerris, W. and Nicholson, R. (Eds.) Phenolic compound biochemistry. $1^{\text {st }}$ ed. Netherlands: Springer, pp. 1-34.

Wang, G., Deng, S., Liu, J.- Ye, C., Zhou, X. and Chen, L. (2017). Cell damage caused by ultraviolet B radiation in the desert cyanobacterium Phormidium tenue and its recovery process. Ecotoxicology and Environmental Safety, 144, 315-320.

Wang, H., Cao, G. and Prior, R.L. (1997). Oxygen radical absorbing capacity of anthocyanins. Journal of Agricultural and Food Chemistry, 45, 304-309.

Xiong, F.S. and Day, T.A. (2001). Effect of solar ultraviolet-B Radiation during springtime ozone depletion on photosynthesis and biomass production of Antarctic vascular plants. Plant Physiology, 125, 738-751.

Xu, C., Natarajan, S. and Sullivan, J.H. (2008). Impact of solar ultraviolet-B radiation on the antioxidant defense system in soybean lines differing in flavonoid contents. Environmental and Experimental Botany, 63, 39-48.

Xue, L., Zhang, Y., Zhang, T., An, L. and Wang, X. (2005). Effects of enhanced ultraviolet-B radiation on algae and cyanobacteria. Critical Reviews in Microbiology, 31, 7-89.

Yamasaki, H. (1997). A function of colour. Trends in Plant Science, 2(1), 7-8.

Yano, J. and Yachandra, V. (2014). $\mathrm{Mn}_{4} \mathrm{Ca}$ Cluster in Photosynthesis: Where and how water is oxidized to dioxygen. Chemical Reviews, 114, 4175-4205.

Yokawa, K., Kagenishi, T. and Baluška, F. (2016). UV-B induced generation of reactive oxygen species promotes formation of BFA-induced compartments in cells of Arabi- 
dopsis root apices. Frontiers in Plant Science, 6:1162. DOI:10.3389/fpls.2015.01162.

Yu, G.H., Li, W., Yuan, Z.Y., Cui, H.Y., Lv, C.G., Gao, Z.P., Han, B., Gong, Y.Z. and Chen, G.X. (2013). The effects of enhanced UV-B radiation on photosynthetic and biochemical activities in super-high-yield hybrid rice Liangyoupeijiu at the reproductive stage. Photosynthetica, 51(1), 33-44.

Zhang, J., Hu, X., Henkow, L., Jordan, B.R. and Strid, A (1994). The effects of ultraviolet-B radiation on the $\mathrm{CF}_{0} \mathrm{~F}_{1}$ -ATPase. Biochimica et Biophysica Acta, 1185, 295-302.

Zhang, X.R., Chen, Y.H., Guo, Q.S., Wang, W.M., Liu, L., Fan, J., Cao, L.P. and Li, C. (2017). Short-term UV-B radiation effects on morphology, physiological traits and accumulation of bioactive compounds in Prunella vulgaris L. Journal of Plant Interactions, 12(1), 348-354.
Zhou, R., Su, W.H., Zhang, G.F., Zhang, Y.N. and Guo, X.R. (2016). Relationship between flavonoids and photoprotection in shade-developed Erigeron breviscapus transferred to sunlight. Photosynthetica, 54(2), 201-209.

Zlatev, Z.S., Lidon, F.J.C. and Kaimakanova, M. (2012). Plant physiological responses to UV-B radiation. Emirates Journal of Food and Agriculture, 24(6), 481-501.

Zwinkels, J. (2016). Light, Electromagnetic Spectrum. In Luo, R. (Ed.) Encyclopedia of Color Science and Technology. New York (NY): Springer Science+Business Media, pp. $843-849$.

Received: October 11, 2020

Accepted: March 11, 2021 